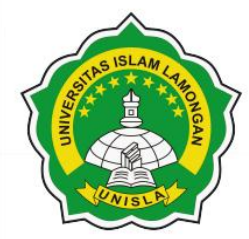

Available online at

\title{
Environmental Impact of C Excavation Mining Activities in Banyakan
}

\section{District}

\author{
${ }^{1}$ Romadhon, ${ }^{2}$ Salwa Nabilah \\ ${ }^{1}$ Civil Engineering, Universitas Kadiri. \\ ${ }^{2}$ Civil Engineering, Universitas Islam Lamongan \\ Email:1 romadhon@unik-kediri.ac.id, ${ }^{2}$ salwanabilah@unisla.ac.id
}

\section{A R T I C L E IN F O}

\section{Article History :}

Article entry : 2021-10-10

Article revised : 2021-11-14

Article received : 2021-12-15

\section{Keywords :}

Environmental Impact, C Excavation, Kediri

\section{IEEE Style in citing this} article :

Romadhon and S. Nabila, "Environmental Impact of $C$ Excavation Mining Activities in Banyakan District," CIVILA, vol. 6, no. 2, pp. 245-256, 2021.

\begin{tabular}{l} 
A B S T R A C T \\
\hline C Excavation mining activities in Banyakan District, Kediri \\
Regency have been going on for a long time. This is necessary to \\
support the creation of good infrastructure and become one of the \\
cornerstones for development progress, but in its implementation, \\
it must pay attention to the preservation of the natural \\
environment. Therefore, it is necessary to research to balance the \\
two things. This study uses a descriptive analysis method with a \\
quantitative approach, survey, and interview methods for data \\
collection. Afterward, the survey data were analyzed by non- \\
parametric test using the free K-sample test, validity and \\
reliability tests, and quantitative analysis using the Analytical \\
Hierarchy Process (AHP) method. The results of the discussion \\
found environmental damage due to C excavation activities which \\
often occur and have a major impact in Tiron Village, Banyakan \\
District, including damage to road infrastructure, air pollution, \\
and loss of rural feel. Therefore, to overcome this, several \\
responses that can be taken include all parties having to allocate \\
special funds for road infrastructure improvements, policies from \\
the government that are in favor of the community and the \\
environment, and reclamation of ex-mining land to restore a rural \\
feel and good standard air quality.
\end{tabular}

Copyright (C) 2021 Romadhon, dkk. This work is licensed under a Creative Commons AttributionShareAlike 4.0 International License. Allows readers to read, download, copy, distribute, print, search, or link to the full texts of its articles and allow readers to use them for any other lawful purpose. 


\section{Introduction}

Increasing development requires humans to develop as well, both in terms of quality and quantity. Likewise, with the development of infrastructure that requires excavation materials, especially $\mathrm{C}$ excavation [1]. Therefore, mining activities for $\mathrm{C}$ excavation are increasingly frequent [2]. C excavation mining activity is the initial part of the development process of a project, while the results from mining are soil, gebal stone, sand, and also crushed stone [3]. C Excavation mining activities are really needed to support development and also have an impact on the surrounding community [4][5], but these activities also have an impact on the environment, these things cannot be denied [6]. Floods and landslides are real impacts of mining activities [7]. Therefore, an effort from various parties is needed to preserve the natural environment, so as not to cause damage that results in the cessation of development [8]. The largest $\mathrm{C}$ excavation mining in the Kediri area is in the Banyakan District, precisely in the Tiron Village. The village has abundant wealth because it is located on the slopes of Mount Wilis actually experiences drought even in the rainy season [9]. In addition, air pollution and road damage due to truck traffic carrying excavated materials are also felt by local residents. That incident is one of the environmental impacts of the mining activity of C Excavation in the area [10].

Indeed, in Article 33 paragraph 3 of the 1945 Constitution it is stated that "earth, water and natural resources contained therein are controlled by the state and can be used for the prosperity of the people", but in its implementation it must pay attention to the preservation of the natural environment, therefore in the Regulation of the Minister of Energy and Mineral Resources Number 26 of 2018, it is explained that every company that carries out mining is required to conserve, manage and monitor the environment against pollution and damage [11][12]. This research is very necessary because in fact, mining entrepreneurs seem indifferent to these regulations, as evidenced by the negative impact of mining activities on the environment which is felt directly by the surrounding community [13][14][15]. This situation made the villagers of Tiron refuse by writing a letter to the Regent of Kediri and the DPRD of Kediri Regency. Yet so far there has been no effort from the Kediri district government to suppress the impact of mining activities [10].

This study aims to find out how the categorization of environmental impacts caused by $\mathrm{C}$ excavation mining activities in the Banyakan District and also how the efforts made to reduce the impact on the environment by the government and also parties involved in $\mathrm{C}$ excavation mining activities, especially some mining entrepreneurs and the community in 
Tiron Village, Banyakan District. It is hoped that with this research related parties can jointly carry out development and maintain the natural environment.

\section{Literature Review}

\subsection{Extractive or Minerals}

According to Article 33 of the 1945 Constitution, all excavated materials contained in the Indonesian mining jurisdiction are national assets and are controlled and used as much as possible for the prosperity of the people. Excavated materials are chemical elements of minerals, ores, and all kinds of rocks, including starting rock which is a natural deposit. Excavated materials are divided into three groups, such as A excavation which is classified as strategic minerals, B excavation is classified as a group of vital minerals, and $\mathrm{C}$ excavation, which is not classified as strategic or vital. The division of the three groups of minerals is based on the importance of the minerals in question for the country. Strategic minerals are used for the defense and security of the State or to ensure the economy of the State. Vital minerals can be interpreted as minerals that can guarantee the livelihood of many people [16].

$\mathrm{C}$ excavation group is a mineral that is considered to indirectly affect the livelihood and national security. Virtually the use of the term $\mathrm{C}$ excavation is no longer appropriate because it has been regulated in Law no. 4 of 2009 the use of the term $\mathrm{C}$ excavation has been changed to "the rocks", but it is commonly referred to as C excavation [17]. "The rocks" is a mining material commonly used for infrastructure projects such as sand, crushed stone, soil and so on [16].

This study obtained data from surveys, then the data were analyzed by nonparametric tests using the free K-sample test, validity and reliability tests, and quantitative analysis using the Analytical Hierarchy Process (AHP) method. Which, it can make the novelty in this research. This research is worthwhile to help improve road infrastructure, reclaim ex-mining land, and restore a rural feel to get good air quality.

\subsection{Environmental Impact}

Environment according to Law no. 32 of 2009 is the unity of space, objects, conditions and living things that affect nature, the continuity of life, and the welfare of humans and other living things [18]. Environmental impact is the effect of changes in the environment caused by an activity that is in direct contact with the environment. Activities in the form of mining, excavation, logging and so on that exceed the standard criteria can cause environmental damage [19]. 


\section{Research Method}

The data used in this study were obtained from field survey and interview methods. Observations were carried out directly at the excavation site in Tiron Village, Banyakan District. Questionnaire instruments are used to obtain primary data in the field. The sample in this study were parties related to $\mathrm{C}$ excavation in Tiron Village using purposive sampling, which selected samples that were directly related to the object of research. Meanwhile, for data processing using descriptive analysis method with a quantitative approach. The survey data were analyzed by non-parametric test using the free K-sample test / Kruskal Wallis H test, followed by the Validity Test and Reliability Test, afterwards, the test results were continued with the analysis of the Analytical Hierarchy Process (AHP) method. After that, with expert recommendations, a strategy for managing the impact of $\mathrm{C}$ excavation activities in the Banyakan District was developed.

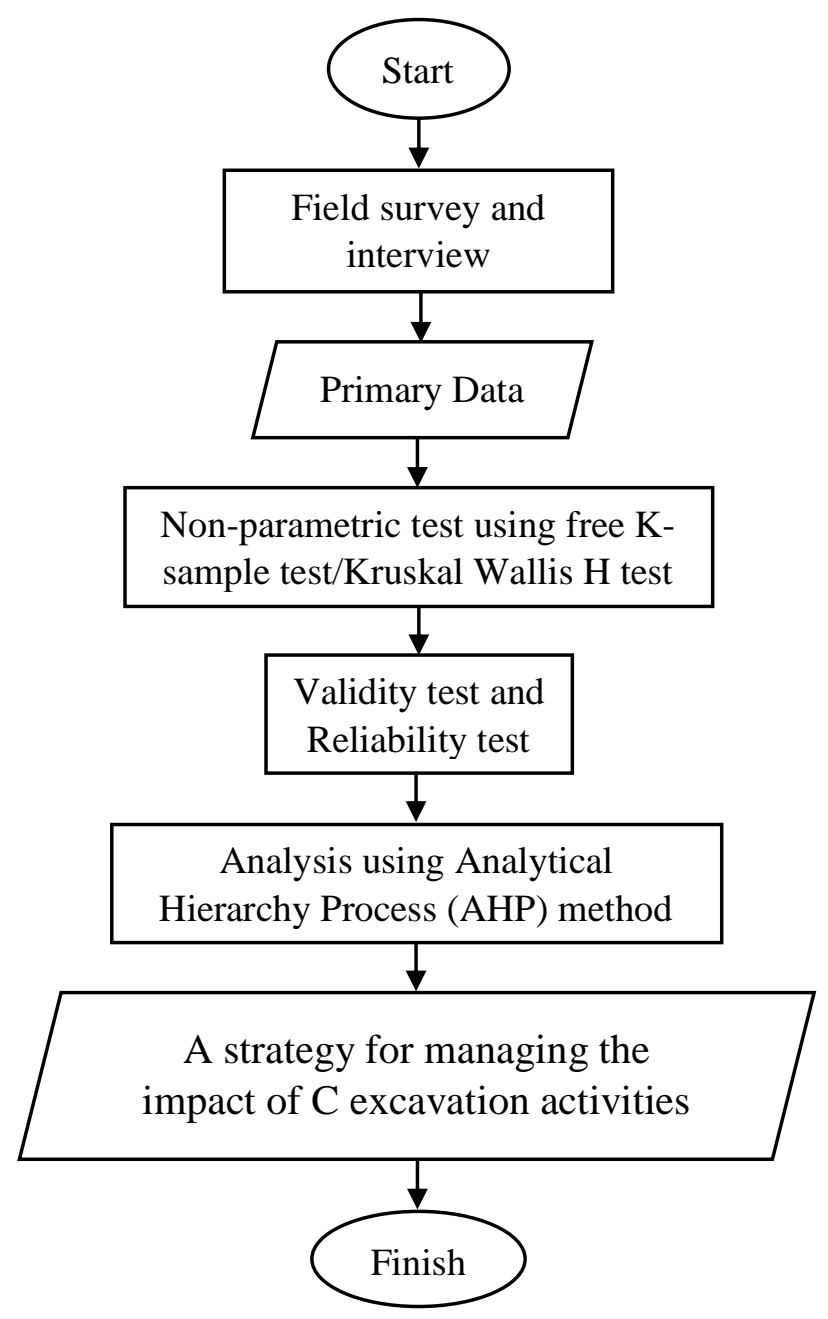

Source: Research Process

Figure 1. Flowchart of this research 


\section{Results and Discussions}

\subsection{Observation Results}

The research data was obtained from observation and reference studies related to the topic of this research. With purposive sampling technique obtained 6 expert respondents and 30 general respondents. Initial data analysis begins by collecting the impacts that occur due to C excavation activities in Tiron Village, Banyakan District. Hereafter the data is validated by experts who have experience and are directly related to field activities with expert questionnaire instruments. The results of the expert questionnaire are as follows:

Table 1. Impacts of C Excavation Activity

\begin{tabular}{cl}
\hline X & \multicolumn{1}{c}{ Impacts } \\
\hline X1 & Landslide \\
X2 & Damage to road infrastructure \\
X3 & Air pollution \\
X4 & Flood \\
& \\
X5 & Missing the rustic feel \\
X6 & Decrease in wildlife \\
& \\
X7 & There is a conflict in the village \\
\hline
\end{tabular}

\begin{tabular}{cl}
\hline $\mathrm{X}$ & \multicolumn{1}{c}{ Impacts } \\
\hline $\mathrm{X} 8$ & Reduced agricultural land \\
$\mathrm{X} 9$ & Reduced availability of ground water \\
$\mathrm{X} 10$ & Land surface changes (holes) \\
$\mathrm{X} 11$ & There are frequent accidents on the \\
& transportation route \\
$\mathrm{X} 12$ & Loss of fertile soil \\
$\mathrm{X} 13$ & There are health problems for local \\
& residents \\
$\mathrm{X} 14$ & Groundwater pollution \\
\hline
\end{tabular}

Source : Processed Data

\subsection{Non Parametric Test}

The non-parametric test here uses the free sample K test / Kruskal Wallis H test for the type of respondent's work. If the value of Asymp.Sig > 0.05 then the respondent's answer can be accepted and it is stated that there is no difference in perception. The results of the Kruskal Wallis $\mathrm{H}$ test for the effect of the type of work of the respondent with the respondent's answer using IBM SPSS V.24 obtained the following results:

\begin{tabular}{l|r}
\multicolumn{2}{c}{ Test Statistics } \\
& Persepsi \\
\hline Kruskal-Wallis H & 10.607 \\
\hline df & 5 \\
\hline Asymp. Sig. & .060 \\
\hline \multicolumn{2}{|c}{ a. Kruskal Wallis Test } \\
b. Grouping Variable: \\
Jabatan \\
\multicolumn{2}{l}{ Source: Processed Data }
\end{tabular}

Figure 2. The results of the work influence test with the respondent's answers

From the calculation output using IBM SPSS V.24 shows Asymp.Sig $0.06>0.05$, so it is declared accepted and there is no difference in the perception of the respondent's answer with the respondent's job. 


\subsection{Validity Test}

Validity test is done by comparing the calculated $r$ value with the table $r$ value, or by looking at the significant value (Sig.2-tailed). If the value of $r$ count $>r$ table, then it is declared valid or if the value is Significant $<0.05$ then it is declared valid and vice versa. From the results of the validity test using IBM SPSS V.24, it is stated that the overall results of the questionnaire are valid because the significant value is $<0.05$.

\subsection{Reliability Test}

The reliability test was carried out by looking at the Cronbach Alpha coefficient value, if the Cronbach Alpha coefficient value > 0.6 then the questionnaire was declared reliable. From the results of reliability testing using IBM SPSS V.24, it was found that the questionnaire was reliable because the Cronbach Alpha value was $>0.6$, and it could be continued in the next analysis.

\subsection{Analytical Hierarchy Process}

This analysis begins with a pairwise matrix comparison to determine element weights, followed by a matrix consistency test, and impact categorization. The comparison of the magnitude of the impact and the frequency of the impact can be seen in the following table:

Table 2. Comparison of Pairwise Matrix

\begin{tabular}{llllll}
\hline & $\begin{array}{l}\text { Very } \\
\text { High }\end{array}$ & High & Medium & Low & $\begin{array}{l}\text { Very } \\
\text { Low }\end{array}$ \\
Very High & 1.00 & 2.00 & 3.00 & 4.00 & 5.00 \\
High & 0.50 & 1.00 & 2.00 & 3.00 & 4.00 \\
Medium & 0.33 & 0.50 & 1.00 & 2.00 & 3.00 \\
Low & 0.25 & 0.33 & 0.50 & 1.00 & 2.00 \\
Very Low & 0.20 & 0.25 & 0.33 & 0.50 & 1.00 \\
Total & $\mathbf{2 . 2 8}$ & $\mathbf{4 . 0 8}$ & $\mathbf{6 . 8 3}$ & $\mathbf{1 0 . 5 0}$ & $\mathbf{1 5 . 0 0}$ \\
\hline
\end{tabular}

Source: Processed Results

After comparing the magnitude of the impact and the frequency of the impact as shown in the table above, it is continued with the calculation of the weight of the elements by dividing the number of elements by the value of each element, as shown in the following table: 
Table 3. Elemental Weight Calculation

\begin{tabular}{lcccccccc}
\hline & $\begin{array}{l}\text { Very } \\
\text { High }\end{array}$ & High & Medium & Low & $\begin{array}{l}\text { Very } \\
\text { Low }\end{array}$ & Total & Average & Percentage \\
\hline $\begin{array}{l}\text { Very } \\
\text { High }\end{array}$ & 0.438 & 0.490 & 0.439 & 0.381 & 0.333 & 2.081 & 0.416 & $100.00 \%$ \\
High & 0.219 & 0.245 & 0.293 & 0.286 & 0.267 & 1.309 & 0.262 & $62.90 \%$ \\
Medium & 0.146 & 0.122 & 0.146 & 0.190 & 0.200 & 0.805 & 0.161 & $38.69 \%$ \\
Low & 0.109 & 0.082 & 0.073 & 0.095 & 0.133 & 0.493 & 0.099 & $23.68 \%$ \\
Very Low & 0.088 & 0.061 & 0.049 & 0.048 & 0.067 & 0.312 & 0.062 & $14.99 \%$ \\
Total & 1.000 & 1.000 & 1.000 & 1.000 & 1.000 & 5.000 & & \\
\hline
\end{tabular}

Source: Processed Results

Table 4. Elemental Weight

\begin{tabular}{lccccc}
\hline & $\begin{array}{l}\text { Very } \\
\text { Low }\end{array}$ & Low & Medium & High & $\begin{array}{l}\text { Very } \\
\text { High }\end{array}$ \\
\hline Weight & 0.150 & 0.237 & 0.387 & 0.629 & 1.000 \\
\hline \multicolumn{7}{l}{ Source: Processed Results }
\end{tabular}

The next analysis is to test the consistency of the matrix by looking at the maximum eigen value ( $K$ max) must be close to the number of elements (n) and the rest of the eigen value is close to zero. The consistency calculation is done by multiplying the average element with the original matrix, so that the $\Lambda$ max value is obtained as follows:

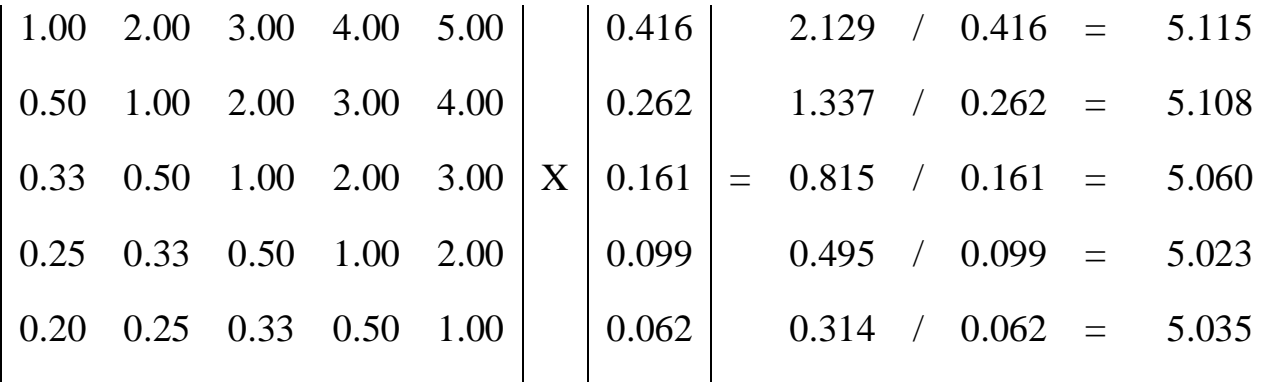

$$
\begin{aligned}
& \mathrm{n}=5 \text {, then } \Lambda_{\max }=5.068
\end{aligned}
$$

From the results of the matrix consistency test calculation, the maximum eigen value $(\kappa \max )$ is 5.068 , the value is close to 5 which is the number of elements, and the remainder of the eigen value is 0.068 which means it is close to zero, it is stated that the matrix is consistent. Then to test the consistency of the hierarchy and accuracy with the large number of elements 5, the amount of Consistency Ratio Index (CRI) is 1.12.

$$
\text { Consistency Index }(\mathrm{CI})=\left(\kappa_{\max }-\mathrm{n}\right) /(\mathrm{n}-1)
$$




\section{Consistency Ratio $(\mathrm{CR})=\mathrm{CI} / \mathrm{CRI}<10 \%$}

From the calculation obtained a Consistency Index of 0.017 and a Consistency Ratio of $0.015<10 \%$, then the hierarchy is consistent and has high accuracy.

The next calculation is to calculate the average value between the frequency value and the magnitude of the impact, by multiplying each weight value of the frequency element and the magnitude of the impact by the number of frequency elements and the magnitude of the impact from the questionnaire results then divided by the number of variables $(\mathrm{X})$. The results of the multiplication are then analyzed for the factor values with the equation:

$$
\mathrm{F}=\mathrm{L}+\mathrm{I}-(\mathrm{L} \times \mathrm{I})
$$

F: Factor Value (with a scale of 0-1)

\section{L: Frequency}

I: Impact Magnitude

The results of the calculation of the Factor Value as shown in the following table:

Table 5. Factor Value

\begin{tabular}{lllll}
\hline $\mathrm{X}$ & The Impacts & $\begin{array}{l}\text { Frequency } \\
\text { Average }\end{array}$ & $\begin{array}{l}\text { Average } \\
\text { Value of } \\
\text { Impact }\end{array}$ & $\begin{array}{l}\text { Factor } \\
\text { Value (F) }\end{array}$ \\
\hline $\mathrm{X} 1$ & Landslide & 0.317 & 0.447 & 0.623 \\
$\mathrm{X} 2$ & Damage to road infrastructure & 0.371 & 0.699 & 0.810 \\
$\mathrm{X} 3$ & Air pollution & 0.476 & 0.544 & 0.761 \\
$\mathrm{X} 4$ & Flood & 0.370 & 0.418 & 0.634 \\
$\mathrm{X} 5$ & Missing the rustic feel & 0.284 & 0.641 & 0.743 \\
$\mathrm{X} 6$ & Decrease in wildlife & 0.182 & 0.387 & 0.499 \\
$\mathrm{X} 7$ & There is a conflict in the village & 0.145 & 0.206 & 0.321 \\
$\mathrm{X} 8$ & Reduced agricultural land & 0.337 & 0.481 & 0.656 \\
$\mathrm{X} 9$ & Reduced availability of ground water & 0.287 & 0.505 & 0.647 \\
$\mathrm{X} 10$ & Land surface changes (holes) & 0.365 & 0.410 & 0.625 \\
$\mathrm{X} 11$ & There are frequent accidents on the & 0.318 & 0.308 & 0.528 \\
& transportation route & & & \\
$\mathrm{X} 12$ & Loss of fertile soil & 0.220 & 0.313 & 0.464 \\
$\mathrm{X} 13$ & $\begin{array}{l}\text { There are health problems for local } \\
\text { residents }\end{array}$ & 0.350 & 0.473 & 0.657 \\
$\mathrm{X} 14$ & Groundwater pollution & 0.180 & 0.209 & 0.351 \\
\hline
\end{tabular}

Source: Processed Results 
From the calculation above, then proceed with an analysis of the impact categories by entering the impacts that occur into groups based on the Factor Values above. The grouping of these impacts is in accordance with the analysis of the impact categories in SNI 8615:2018. The following is a standard table of impact categories:

Table 6. Standard of Impact Categories

\begin{tabular}{lll}
\hline Factor Value & Categories & Handling Step \\
\hline $0.7-1.0$ & High & Impact reduction must be carried out \\
$0.4-0.7$ & Medium & Corrective steps are required under certain conditions \\
$0.0-0.4$ & Low & Corrective steps if necessary
\end{tabular}

Source: SNI 8615:2018 [20]

Based on the table above, the impact can be obtained with low, medium and high categories as shown in the following table:

Table 7. Categories of Impact

\begin{tabular}{llll}
\hline X & Risk Factor & $\begin{array}{l}\text { Factor } \\
\text { Value }\end{array}$ & Categories \\
\hline X2 & Damage to road infrastructure & 0.810 & High \\
X3 & Air pollution (dust and smoke) & 0.761 & High \\
X5 & Missing the rustic feel & 0.743 & High \\
X13 & There are health problems for local residents & 0.657 & Medium \\
X8 & Reduced agricultural land & 0.656 & Medium \\
X9 & Reduced availability of ground water & 0.647 & Medium \\
X4 & Flood & 0.634 & Medium \\
X10 & Land surface changes (holes) & 0.625 & Medium \\
X1 & Landslide & 0.623 & Medium \\
X11 & There are frequent accidents on the transportation route & 0.528 & Medium \\
X6 & Decrease in wildlife & 0.499 & Medium \\
X12 & Loss of fertile soil & 0.464 & Medium \\
X14 & Groundwater pollution & 0.351 & Low \\
X7 & There is a conflict in the village & 0.321 & Low \\
\hline S0urce: Processed Results & &
\end{tabular}

Source: Processed Results

\subsection{Impact Management Analysis}


From the previous discussion, it is known that the impact category is from low to high category, then the results are validated by experts and all experts agree with these results. Damage to road infrastructure (X2), air pollution (X3) and loss of rustic feel (X5) are in the high category because they have a high impact magnitude and frequent impact frequency. Then for the impact of the high category, the handling is analyzed with expert recommendations. The expert recommendations for handling high category impacts are as follows:

a. Communities, entrepreneurs, and the government can allocate special funds for infrastructure improvements from excavations or excavation taxes.

b. The government is expected to make policies that are in favor of the community and environmental sustainability and prohibit mining activities without a permit.

c. Revocation of permits for companies that do not carry out reclamation on former excavations.

d. Reclamation and replanting of trees are carried out on $\mathrm{C}$ excavated former lands so that it can be used as a tourist location that would improve the community's economy and return to a beautiful rustic feel.

\section{Conclusion}

C excavation activities are indeed needed to support the creation of good infrastructure and become one of the foundations for development progress, but in its implementation, it must pay attention to the preservation of the natural environment. Environmental damage due to $\mathrm{C}$ excavation activities that often occur and have a major impacts in Tiron Village, Banyakan District based on the results of this study include damage to road infrastructure, air pollution (dust and smoke), missing the rustic feel, there are health problems for local residents, reduced agricultural land, reduced availability of ground water, flood, land surface changes (holes), landslide, there are frequent accidents on the transportation route, decrease in wildlife, loss of fertile soil, groundwater pollution, and there is a conflict in the village. Therefore, all parties must work together to overcome this, several responses that can be taken to deal with these impacts include all parties having to allocate special funds for road infrastructure improvements, policies from the government that are in favor of the community and the environment, and land reclamation is carried out $\mathrm{C}$ excavation former lands to restore a rustic feel for the good air quality standards.

\section{References}

[1] A. A. Wardoyo and L. Hendrajaya, "Fisika penambangan bahan galian C," J. Pendidik. Sains dan Teknol., no. 10, pp. 236-241, 2016. 
[2] PricewaterhouseCoopers, "Financial Reporting in the Mining Industry," Financ. Report. Min. Ind., pp. 97-107, 2012, [Online]. Available:

https://www.pwc.com/id/en/publications/assets/eumpublications/financial-reporting-inthe-mining-industry.pdf.

[3] F. Rissamasu, R. Darma, and D. A. Tuwo, "Pengelolaan Penambangan Bahan Galian Golongan C di Kabupaten Merauke,” J. Chem. Inf. Model., 2013.

[4] Asril, "Dampak Pertambangan Galian C Terhadap Kehidupan Masyarakat Kecamatan Koto Kampar Hulukabupaten Kampar,” J. Kewirausahaan, vol. 13, no. 1, pp. 21-38, 2014.

[5] J. Mossa and L. A. James, "Impacts of Mining on Geomorphic Systems," Treatise Geomorphol., vol. 13, no. March, pp. 74-95, 2013, doi: 10.1016/B978-0-12-3747396.00344-4.

[6] A. A. A. Tejioye and C. Odeyemi, "Analysing Impact of Sand Mining in Ekiti State, Nigeria Using GIS for Sustainable Development," World J. Res. Rev., no. 2, pp. 26-31, 2018, [Online]. Available: https://www.researchgate.net/publication/332442546.

[7] Q. Sholihah, W. Kuncoro, S. Wahyuni, S. Puni Suwandi, and E. Dwi Feditasari, "The analysis of the causes of flood disasters and their impacts in the perspective of environmental law," IOP Conf. Ser. Earth Environ. Sci., vol. 437, no. 1, pp. 0-7, 2020, doi: 10.1088/1755-1315/437/1/012056.

[8] W. Sudarma, "Dampak Galian C Terhadap Lingkungan Alam Dan Sosial Budaya Masyarakat Desa Peringsari Kecamatan Selat Kabupaten Karangasem,” Jnana Budaya, vol. volume 19, no. Nomor 2, pp. 249-258, 2014.

[9] Surya.co.id, "Krisis Air Bersih masih Terjadi di Kecamatan Banyakan Kabupaten Kediri meski telah Masuk Penghujan Artikel ini telah tayang di surya.co.id dengan judul Krisis Air Bersih masih Terjadi di Kecamatan Banyakan Kabupaten Kediri meski telah Masuk Penghujan, htt," 2020. .

[10] Duta.co, "Setiap Menit Truk Galian C Melintas, Warga Banyakan Mengadu Bupati Kediri," 2018. .

[11] K. ESDM, Peraturan Menteri ESDM Nomor 26 Tahun 2018. 2018.

[12] A. Maddah and A. Soroush, "A comprehensive numerical study on building-excavation interaction," Civ. Eng. J., vol. 6, no. 2, pp. 326-343, 2020, doi: 10.28991/cej-2020- 
03091474.

[13] N. R. Haddaway et al., "Evidence of the impacts of metal mining and the effectiveness of mining mitigation measures on social-ecological systems in Arctic and boreal regions: A systematic map protocol," Environ. Evid., vol. 8, no. 1, pp. 1-11, 2019, doi: 10.1186/s13750-019-0152-8.

[14] I. Irawan, "Legal Analysis of Coal Mining in Efforts to Maintain The Environmental Sustainability," Humaniora, vol. 7, no. 3, p. 381, 2016, doi: 10.21512/humaniora.v7i3.3592.

[15] A. Y. Emmanuel, C. S. Jerry, and D. A. Dzigbodi, "Review of environmental and health impacts of mining in Ghana," J. Heal. Pollut., vol. 8, no. 17, pp. 43-52, 2018, doi: 10.5696/2156-9614-8.17.43.

[16] L. Moerdijat, "Memahami Galian C," 2019.

[17] Pemerintah RI, "Undang Undang Pertambangan Mineral Dan Batubara," Uu No 4 Tahun 2009 Tentang Pertamb. Dan Batubara, p. 4, 2009.

[18] Undang-undang RI Tahun 32 Nomor 2009 tentang Perlindungan dan Pengelolaan Lingkungan Hidup. .

[19] Putra Saroeli Zebua, "Dampak Penambangan Bahan Galian Golongan C terhadap Sosial Ekonomi Masyarakat dan Lingkungan di Desa Tuwuna Kecamatan Mandrehe Kabupaten Nias Barat,” 2016.

[20] BSN, SNI 8615:2018. . 